\title{
KUALITAS PAPAN PARTIKEL DARI AMPAS BATANG SAGU (Metroxylon spp) DENGAN PEREKAT ALAMI ASAM SITRAT : SIFAT FISIK, MEKANIK DAN KEAWETAN TERHADAP RAYAP TANAH (Coptotermes curvignathus Holmgren)
}

Quality particleboard from dregs of sago (Metroxylon spp) with citric acid as natural adhesive: The phisical, mechanical and termite resistance (Coptotermes curvignathus Holmgren)

\author{
Yonatan Wesly, Dirhamsyah, Dina Setyawati, Nurhaida \\ Fakultas Kehutanan Universitas Tanjungpura Jalan Daya Nasional Pontianak 78124 \\ E-mail: weslyyonatan@gmail.com
}

\begin{abstract}
This study is intended to focus on the concentration of natual citric acid and density including physical and mechanical properties and durability of particleboards towards $C$. curvignathus Holmgren. This research is lifted because research on the use of citric acid as an adhesive is relatively limited.The research's material was taken from waste dreg of Sago and citric acid. The research was carried out in wood workshops, wood processing technology laboratories and forest product technology laboratories, Tanjungpura University Forestry Faculty along with laboratories PT Duta Pertiwi Nusantara. The factors which was used in this study was the concentration of $20 \%-30 \%$ with a density of $0,6 \mathrm{~g} / \mathrm{cm}^{3}$ and $0,7 \mathrm{~g} / \mathrm{cm}^{3}$, based on the weight of the airborne particle, the temperature of pressurization used $180^{\circ} \mathrm{C}$ with pressures of $25 \mathrm{~kg} / \mathrm{cm}^{2}$. Physical and mechanical properties were tested based on JIS A 5908-2003 type 8. Testing of soil termites was carried out by calculating the value of weight reduction and mortality of termiste after 21 days. In this study, The optimum conditions were particle board density 0,7 $\mathrm{g} / \mathrm{cm}^{3}$ and concentration $20 \%$, with qualities that can fulfill several standards of JIS A 59082003 type 8 , with a density of $0,7 \mathrm{~g} / \mathrm{cm}^{3}$ consentrations $30 \%$, resulting in termite mortality values of $100 \%$ and loss $16,92 \%$ of weight.
\end{abstract}

Keywords : Citric acid, concentration, density, termite, sago.

\section{PENDAHULUAN}

Indonesia merupakan negara penghasil sagu terbesar dan memiliki areal tanaman sagu semi budaya di Kalimantan sebesar 20.000 hektar (Badan Litbang Kehutanan, 2007). Sebaran tanaman sagu tersebut terdapat di beberapa daerah, yaitu Papua, Maluku, Riau, Sulawesi, dan Kalimantan. Tanaman sagu yang terdapat di wilayah Kalimantan Barat tumbuh secara alamiah dan tidak teratur (Anonim, 1983 dalam Haryanto dan Pangloli, 1992). Luas areal tanaman sagu menurut data Statistik Perkebunan Indonesia, Direktorat
Jenderal Perkebunan tahun 2015, mencapai 1.054 Ha dengan produksi 241 Ton, yang tersebar di Kabupaten Sambas, Pontianak, Ketapang dan Sanggau.

Sagu dikelola untuk mendapatkan patinya sebagai kebutuhan pangan masyarakat, disisi lain proses pengelolaan pati sagu menghasilkan 3 jenis limbah, yaitu residu selular empulur sagu berserat (ampas), kulit batang sagu (bark), dan air buangan (waste water). Sampai saat ini limbah dari sagu masih belum dimanfaatkan dengan efektif salah satunya adalah ampas sagu. Limbah tersebut bila 
tidak dimanfaatkan akan berdampak negatif bagi lingkungan, untuk menghindari hal tersebut bisa mengolah ampas sagu menjadi produk bermutu seperti papan partikel.

Nurhaida dan Setyawati (2017) telah melakukan penelitian tentang pembuatan papan partikel dari ampas sagu dengan perekat asam sitrat. Hasil penelitian menunjukan bahwa papan yang dibuat dengan kerapatan 0,6 dan konsentrasi 20\% masih belum memenuhi standar, sehingga perlu dilakukan penelitian lebih lanjut mengenai kualitas papan partikel tersebut pada kerapatan papan dan konsentrasi asam sitrat yang lebih tinggi.

Rayap tanah merupakan jenis rayap yang merusak kayu basah maupun kering yang berhubungan atau tidak yang dicirikan dengan adanya tanah dalam kayu yang diserang. Rayap merupakan serangga pemakan kayu (xylophagus) atau bahanbahan yang mengandung selulosa (Nandika, dkk, 2003). Selain itu, rayap adalah salah satu hama yang menimbulkan kerusakan hebat dan kerugian besar pada produk-produk kayu (Haygreen dan Bowyer, 1996). Berdasarkan hal tersebut maka penelitian mengenai siat fisik, mekanik dan keawetan papan partikel dari ampas sagu terhadap rayap tanah perlu dilakukan.

Penelitian ini bertujuan menguji kualitas papan partikel dari ampas batang sagu dengan nilai kerapatan dan perekat alami asam sitrat yang berbeda yang meliputi sifat fisik dan mekanik serta keawetan papan partikel terhadap $C$. curvignathus Holmgren. Menganalisis pengaruh kerapatan dan konsentrasi perekat yang dapat menghasilkan papan partikel dengan kualitas terbaik. Penelitian ini juga diharapkan dapat memberikan informasi kepada masyarakat untuk memanfaatkan limbah dari sagu menjadi papan partikel yang bernilai ekonomi dan mengetahui ketahanannya terhadap serangan rayap tanah serta mengurangi dampak negatif terhadap lingkungan, sehingga menjadi suatu peluang usaha kedepan dan memberikan informasi baru bagi perindustrian kayu.

\section{METODE PENELITIAN}

Penelitian dilaksanakan di Wood Workshop dan di laboratorium Teknologi Pengolahan Kayu Fakultas Kehutanan Universitas Tanjungpura persiapan bahan baku dan aplikasi asam sitrat, pembuatan papan di laboratorium PT. Duta Pertiwi Nusantara serta di laboratorium Teknologi Hasil Hutan Fakultas Kehutanan Universitas Tanjungpura uji ketahanan terhadap rayap. Penelitian dilaksanakan \pm 3 bulan.

Papan partikel dibuat dengan ukuran $30 \mathrm{~cm}$ x $30 \mathrm{~cm} \times 1 \mathrm{~cm}$. Perlakuan yang digunakan dalam penelitian ini adalah kerapatan papan $\left(0,6 \mathrm{~g} / \mathrm{cm}^{3}\right.$ dan $\left.0,7 \mathrm{~g} / \mathrm{cm}^{3}\right)$ dan konsentrasi perekat asam sitrat $(20 \%$ dan 30\%). Pencampuran bahan baku dilakukan secara manual, pengempaan panas dilakukan pada suhu $180^{\circ} \mathrm{C}$ selama 15 menit dan tekanan $25 \mathrm{~kg} / \mathrm{cm}^{2}$. Pengujian sifak fisik dan mekanik mengacu pada Japanese Industrial standart A 5908 - 2003 tipe 8.

Variabel pengamatan meliputi sifat fisik (kerapatan, kadar air, daya serap air dan pengembangan tebal), sifat mekanik (modulus elastisitas, modulus patah, 
keteguhan rekat internal dan kuat pegang sekrup). Pengujian keawetan kayu terhadap rayap tanah mengacu pada Standar Nasional Indonesia (SNI 01-72022006). Sampel uji berukuran $2 \mathrm{~cm} \times 2 \mathrm{~cm} \mathrm{x}$ $1 \mathrm{~cm}$, pengujian dilakukan selama 21 hari, dengan metode umpan paksa. Variabel pengamatan meliputi (mortalitas rayap dan kehilangan berat).

Metode penelitian yang digunakan adalah percobaan faktorial dalam Rancangan Acak Lengkap (RAL), dengan 2 faktor perlakuan yaitu kerapatan sebagai faktor A yang terdiri dari 2 subfaktor dan konsenterasi perekat sebagai faktor B yang terdiri dari 2 subfaktor dengan ulangan sebanyak 3 kali, sehingga didapat 12 kombinasi perlakuan.

HASIL DAN PEMBAHASAN

\section{Sifat Fisik Papan Partikel}

\section{Kerapatan Papan Partikel}

Hasil penelitian menujukkan bahwa nilai rata-rata dari kerapatan papan partikel yang dihasilkan berkisar antara 0,6610 sampai $0,7886 \mathrm{~g} / \mathrm{m}^{3}$. Nilai kerapatan ratarata dapat dilihat pada Gambar 1.

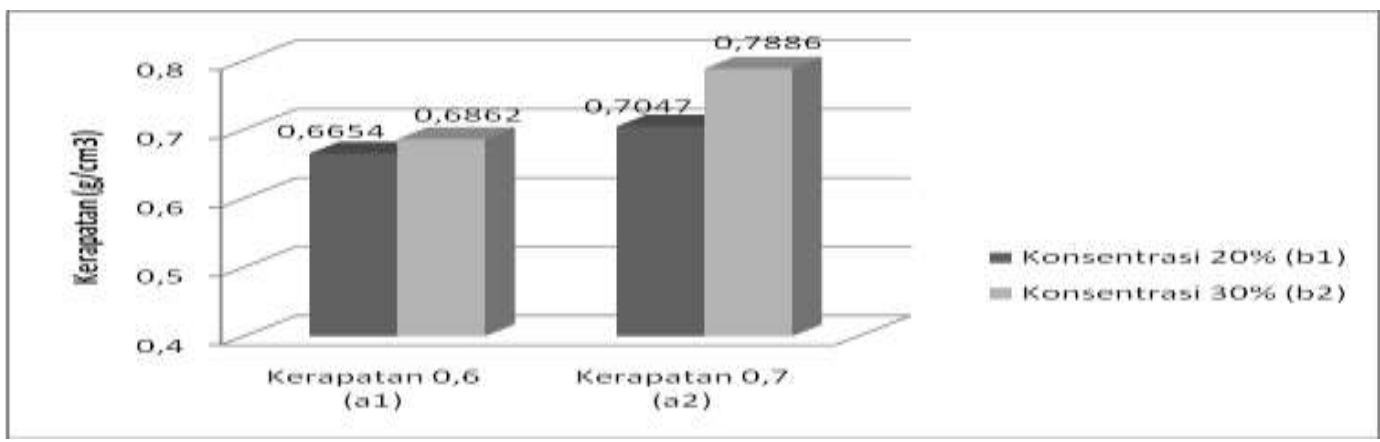

Gambar 1. Kerapatan $\left(\mathrm{g} / \mathrm{m}^{3}\right)$ papan partikel dari ampas batang sagu (Metroxylon spp) dengan perekat alami asam sitrat.

Perbedaan nilai kerapatan papan partikel ampas sagu menghasilkan nilai yang signifikan. Menurut Wulandari (2012), semakin tinggi komposisi perekat maka akan diikuti dengan peningkatan nilai kerapatan. Hal ini disebabkan dengan meningkatnya konsentrasi perekat, maka berat total bahan baku yang digunakan juga akan semakin bertambah besar. Hal serupa juga diungkapkan oleh Fernando dkk (2015), penambahan jumlah asam sitrat akan menambah berat dari papan partikel.

Hasil penelitian ini sejalan dengan penelitian Widyorini dkk (2012), yang meneliti konsentrasi asam sitrat terhadap kualitas papan partikel pelepah nipah, menyatakan bahwa dengan pertambahan bahan baku yang digunakan maka semakin tinggi kerapatan yang dihasilkan. Kerapatan merupakan faktor yang penting yang dapat mempengaruhi kualitas dari papan. Semakin tinggi kerapatan menyeluruh papan dari suatu bahan baku tertentu maka semakin tinggi kekuatan papan (Haygreen dan Bowyer, 1996).

\section{Kadar Air Papan Partikel}

Nilai kadar air papan partikel ampas sagu berkisar antara 8,73 - 12,65\%. Nilai rata-rata kadar air dapat dilihat pada Gambar 2. 


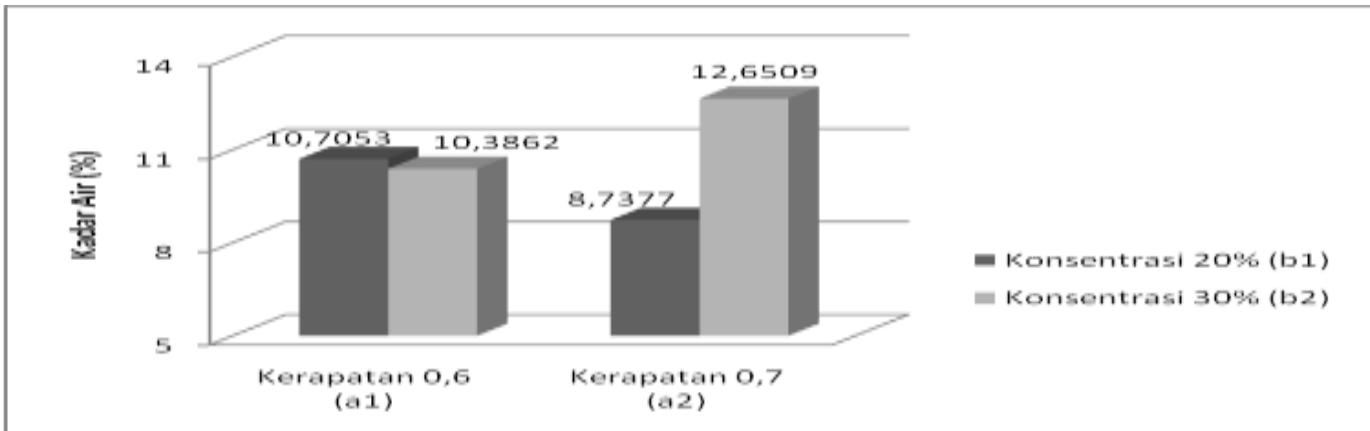

Gambar 2. Kadar air (\%) papan partikel dari ampas batang sagu (Metroxylon spp) dengan perekat alami asam sitrat.

Hasil penelitian menunjukan bahwa papan partikel yang dibuat dengan target kerapatan dan konsentrasi perekat yang tinggi mempengaruhi kadar air. Hal ini diduga dipengaruhi oleh jumlah partikel yang ada dan interaksi antara hubungan kerapatan dan konsentrasi berpengaruh terhadap kadar air.

Konsentrasi perekat diduga berpengaruh terhadap tingginya nilai kadar air, hal ini dikarenakan dengan meningkatnya konsentrasi perekat asam sitrat, maka bertambah pula jumlah air yang digunakan untuk pencampuran perekat. Menurut Boywer dkk (2003), apabila pada papan partikel menggunakan perekat cair maka kadar air papan akan bertambah $4-6 \%$. Peningkatan nilai kadar air pada kerapatan 0,7 g/cm2 konsentrasi $30 \%$ diduga ikatan antar partikel yang kurang kompak, hal ini dapat dilihat dari papan yang cenderung memiliki tektstur yang lunak.

JIS A 5908- 2003 mengisyaratkan nilai kadar air yang dihasilkan kurang dari $13 \%$, dengan demikian semua papan partikel yang telah di hasilkan telah memenuhi standar yang ditetapkan.

\section{Pengembangan Tebal Papan Partikel}

Pengembangan tebal air papan partikel ampas sagu berkisar antara 17, $4743-21,7969 \%$. Nilai rata-rata kadar air dapat dilihat pada Gambar 3.

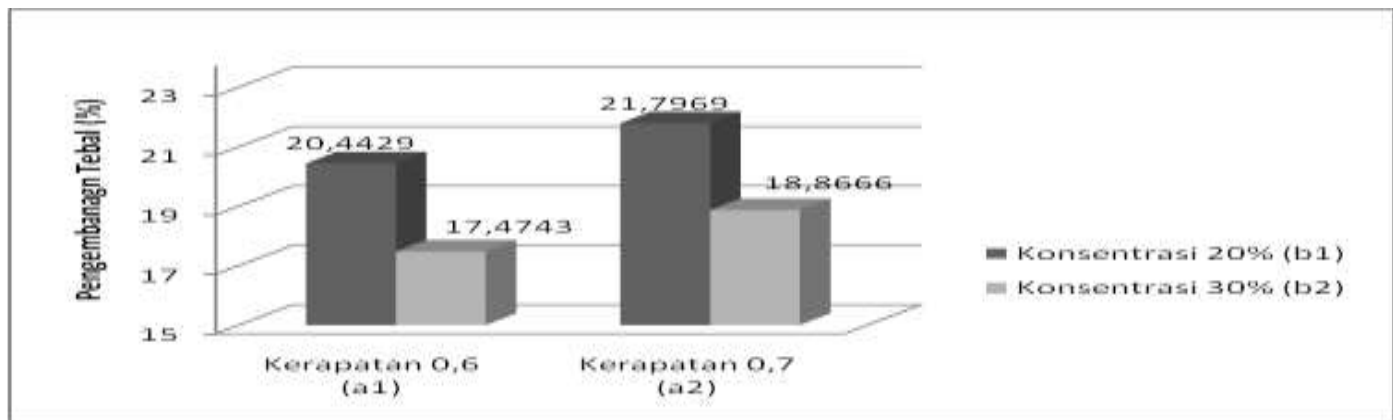

Gambar 3. Pengembangan tebal (\%) papan partikkel dari ampas batang sagu (Metroxylon spp) dengan perekat alami asam sitrat.

Pengembangan tebal ini diduga proses perendaman air akan terlebih berkaitan dengan dengan adanya dahulu merusak ikatan-ikatan antara penyerapan air oleh papan partikel, pada perekat dan partikel sehingga semakin 
lama terjadilah perubahan dimensi. Iswanto dkk (2005) mengemukakan bahwa pengembangan tebal diduga adanya hubungan erat dengan absorsi air, karena dengan semakin banyak air yang diserap oleh papan partikel dan memasuki struktur serat maka semakin besar perubahan dimensi yang terjadi.

Semakin banyak partikel ampas sagu maka semakin meningkatnya pengembangan papan partikel, hal ini disebabkan oleh struktur partikel ampas sagu sangat mudah menyerap air, sehingga pada kerapatan 0,7 dengan banyaknya jumlah partikel yang digunakan sehingga penyerapan air tinggi dan akhir berdampak terhadap perubahan demensi. Menurut Maulana dkk (2015), banyaknya jumlah partikel yang digunakan dapat mempengaruhi nilai pengembangan tebal suatu papan, hal ini dikarenakan semakin banyak partikel maka semakin besar potensi papan untuk menyerap air dan pengembangan tebal semakin meningkat.

\section{Daya Serap Air Papan Partikel}

Daya serap air papan partikel ampas sagu berkisar antara 60,11\% $115.27 \%$. Nilai rata-rata kadar air dapat dilihat pada Gambar 4.

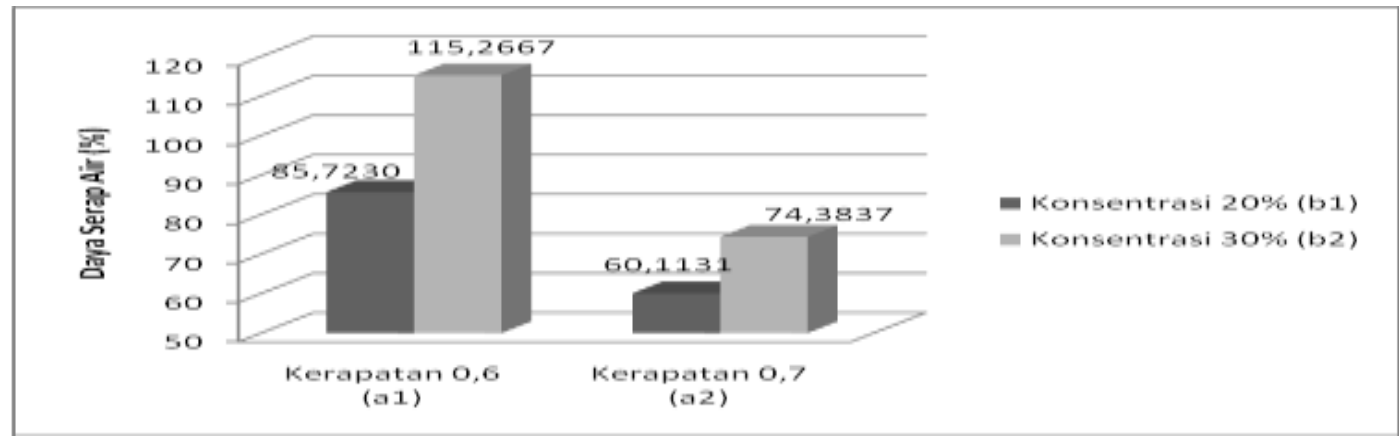

Gambar 4. Daya serap air (\%) papan partikel dari ampas batang sagu (Metroxylon spp) dengan perekat alami asam sitrat.

Semakin rendah nilai kerapatan suatu bahan maka akan semakin mudah air masuk ke dalam struktur serat dari bahan, sehingga semakin banyak air yang diserap dan semakin perubahan dimensi yang ditimbulkan. Sejalan dengan hal tersebut maka dengan dengan meningkatnya kerapatan maka nilai daya serap air akan menurun. Hasil penelitian Lestari dkk (2018), nilai daya serap air akan menurun seiring bertambahnya nilai kerapatan papan, hal ini disebabkan papan partikel semakin padat sehingga sulit untuk air dapat masuk pada bagian papan. JIS A 5908-2003, tidak mensyaratkan nilai daya serap air, namun pengujian daya serap air ini perlu dilakukan agar dapat menentukan penggunaan dari papan partikel ini. Jika dilihat dari nilai daya serap air yang berkisar antara $60,11 \%$ sampai $115.27 \%$ menunjukkan nilai daya serap air yang tinggi, sehingga papan partikel ini direkomendasikan hanya untuk keperluan interior. 
Sifat Mekanik Papan Partikel

5. Keteguhan Lentur/Modulus of Elasticity (MOE)

Keteguhan lentur atau modulus of elasticity (MOE) papan partikel ampas sagu berkisar antara 1640,01 - 7804,32 $\mathrm{kg} / \mathrm{cm}^{2}$ Nilai rata-rata kadar air dapat dilihat pada Gambar 5.

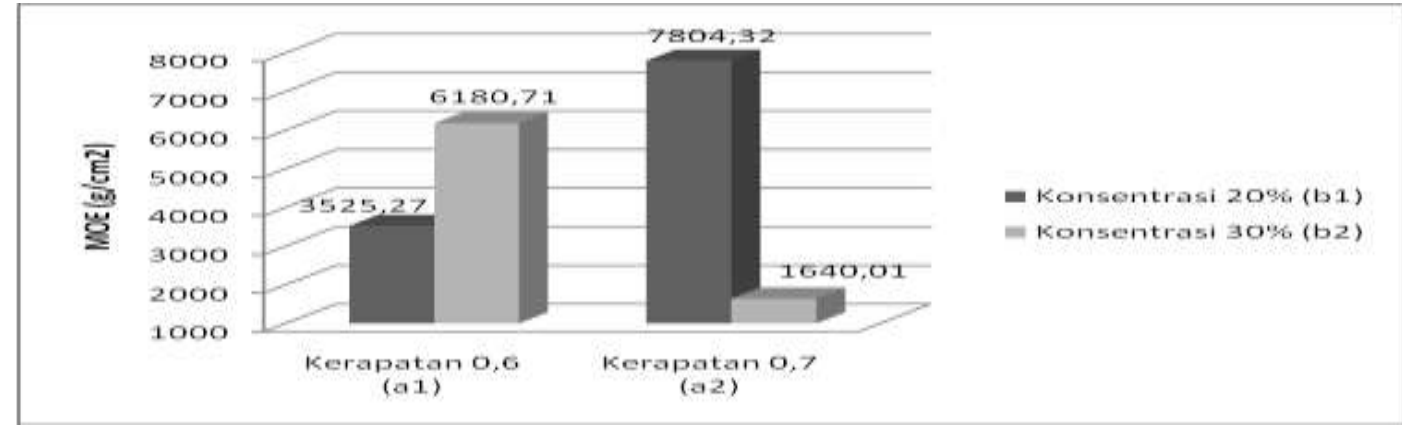

Gambar 5. Modulus of Elasticity $\left(\mathrm{kg} / \mathrm{cm}^{2}\right)$ papan partikel dari ampas batang sagu (Metroxylon spp) dengan perekat alami asam sitrat.

Secara umum pada penelitian ini nilai MOE mengalami peningakatan pada penambahan kerapatan dan konsentrasi perekat, namun hal ini tidak berlaku pada kerapatan 0,7 konsentrasi 30\%, diduga papan tidak maksimal dalam proses pengempaan yang disebabkan oleh kondisi mesin kempa. Peningkatan kerapatan dan konsentrasi perekat tidak berpengaruh terhadap nilai MOE, diduga dalam proses pengempaan tidak meratanya suhu pada mesin kempa, hal ini menyebabkan ikatanikatan ester antara gugus karboksil dari asam sitrat dengan gugus hidroksil $(-\mathrm{OH})$ dari kayu tidak optimal (McSweeny dkk, 2006).

Papan partikel yang dibuat menggunakan bahan non kayu juga dapat mempengaruhi nilai MOE yang dihasilkan. Hal ini dikarenakan bahan baku yang digunakan adalah ampas sagu. Menurut Kiat dalam Jumantara (2011), ampas sagu memiliki kandungan selulosa yang rendah namum mengandung zat ektraktif yang tinggi sehingga mengurangi kekuatan papan partikel dan mengganggu proses perekatan.

\section{Keteguhan Patah/Modulus Of Rupture (MOR)}

Keteguhan patah atau modulus of rupture (MOR) papan partikel ampas sagu berkisar antara 21,3980 - 41,5335 $\mathrm{kg} / \mathrm{cm}^{2}$. Nilai rata-rata kadar air dapat dilihat pada Gambar 6. 
JURNAL HUTAN LESTARI (2019)

Vol. 7 (1) : 166 - 177

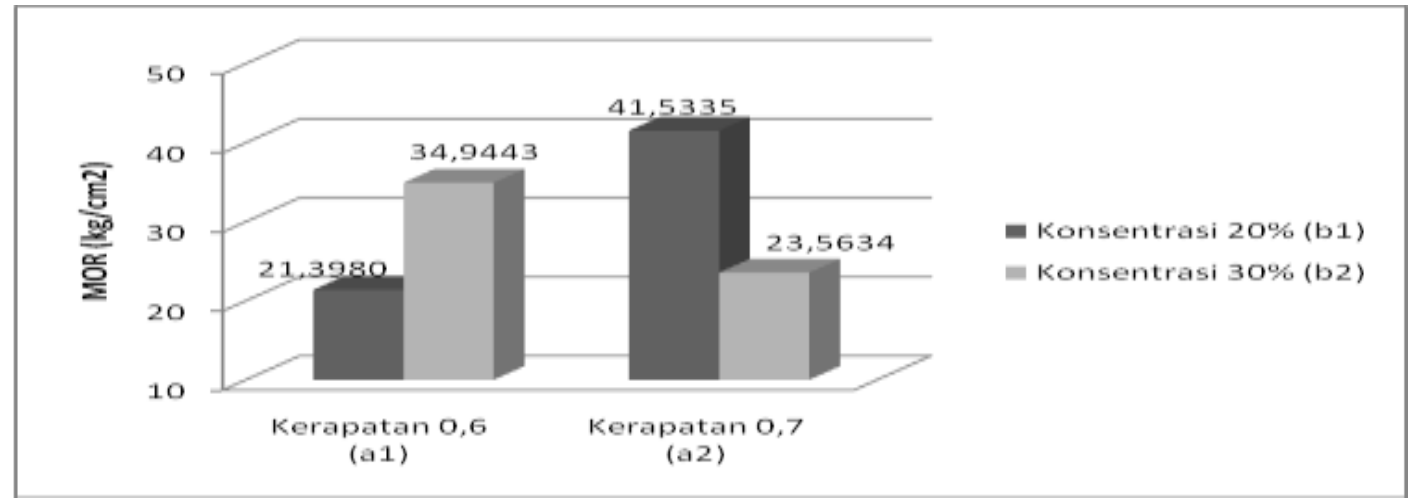

Gambar 6. Modulus of Rupture $\left(\mathrm{kg} / \mathrm{cm}^{2}\right)$ papan partikel dari ampas batang sagu (Metroxylon spp) dengan perekat alami asam sitrat.

Secara umum nilai MOR meningkat dengan meningkatnya kerapatan dan konsentrasi perekat, kecuali pada perlakuan kerapatan 0,7 dan konsentrasi 30\%. Hal ini sejalan dengan penelitian Endriani (2018), dimana penambahan konsenterasi asam sitrat justru nilai MOR cenderung menurun, dapat terlihat dari kondisi papan yang cenderung lunak.

Nilai MOR pun tergolong rendah dari standar yang ditetapkan JIS A 5908- 2003 tipe 8 mensyaratkan nilai MOR $82 \mathrm{~kg} / \mathrm{cm}^{2}$. Hal ini sejalan dengan penelitian Fauziah dkk, (2014) yang menyatakan bahwa partikel yang tidak mengikat dan tidak saling mengisi antara satu dengan yang lain menyebabkan rendah kekuatan patah papan partikel.

7. Keteguhan Rekat/Internal Bonding (IB)

Keteguhan rekat atau internal bonding (IB) papan partikel ampas sagu berkisar antara $1,83-2,41 \mathrm{~kg} / \mathrm{cm}^{2}$. Nilai rata-rata kadar air dapat dilihat pada Gambar 7.

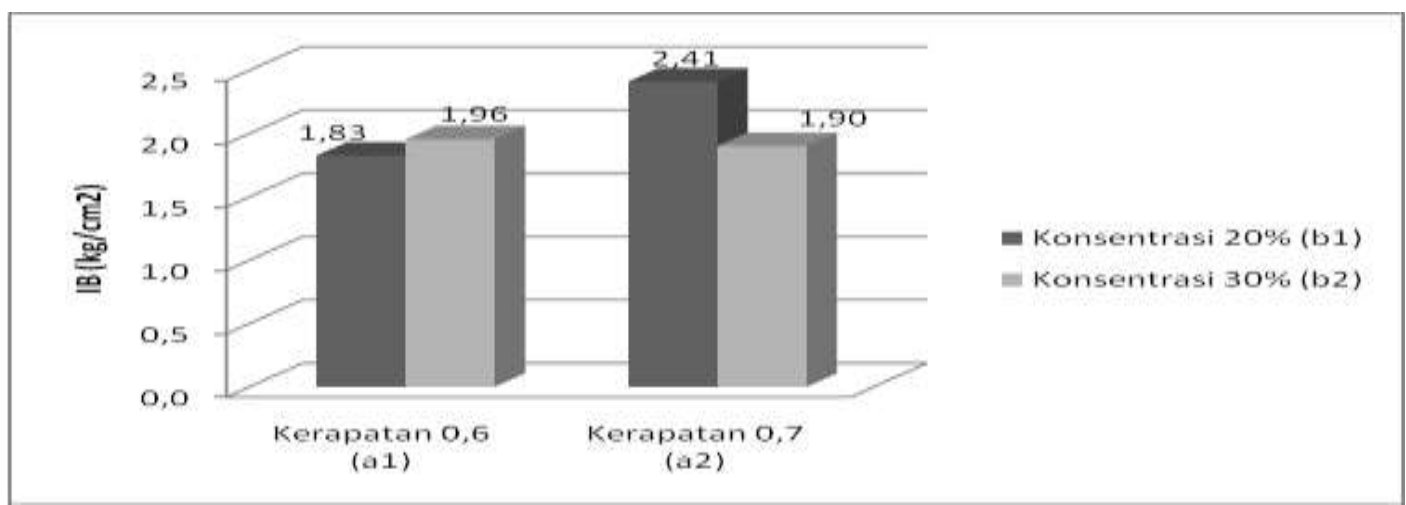

Gambar 7. Internal bonding $\left(\mathrm{kg} / \mathrm{cm}^{2}\right)$ papan partikel dari ampas batang sagu (Metroxylon spp) dengan perekat alami asam sitrat. 
Secara umum semakin meningkat kerapatan dan konsentrasi perekat semakin bertambah nilai IB, hal ini diduga dengan bertambah perekat akan terjadi ikatan yang baik antar partikel. Namun pada kerapatan 0,7 konsentrasi 30\% mengalami penurunan, diduga pada konsentrasi tersebut perekat sudah tidak optimal lagi, hal ini dapat dikarenakan oleh banyaknya jumlah ampas sagu dan tidak merata persebaran perekat pada konsentrasi tersebut, terlihat pada hasil papan yang lebih lunak.

Nilai IB juga dapat dipengaruhi kerapatan, ikatan antar partikel didalam papan yang semakin kompak sehingga keteguhan rekat semakin kuat. Haygreen dan Bowyer (1996), menyatakan bahwa ikatan internal merupakan ukuran tunggal tentang kualitas pembautan suatu papan karena menunjukan kekuatan ikatan antar partikel. JIS A 59082003 mensyaratkan nilai IB $1,5 \mathrm{~kg} / \mathrm{cm}^{2}$, nilai IB pada penelitian ini berkisar antara 2,41 $\mathrm{kg} / \mathrm{cm}^{2}$ sampai $1,83 \mathrm{~kg} / \mathrm{cm}^{2}$, dengan demikian semua nilai telah memenuhi standar yang ditetapkan.

\section{Kuat Pegang Sekrup/ Screw Holding Strenght}

Kuat pegang sekrup atau screw holding strenght papan partikel ampas sagu berkisar antara $18,03-24,50 \mathrm{~kg} / \mathrm{cm}^{2}$. Nilai rata-rata kadar air dapat dilihat pada Gambar 8 .

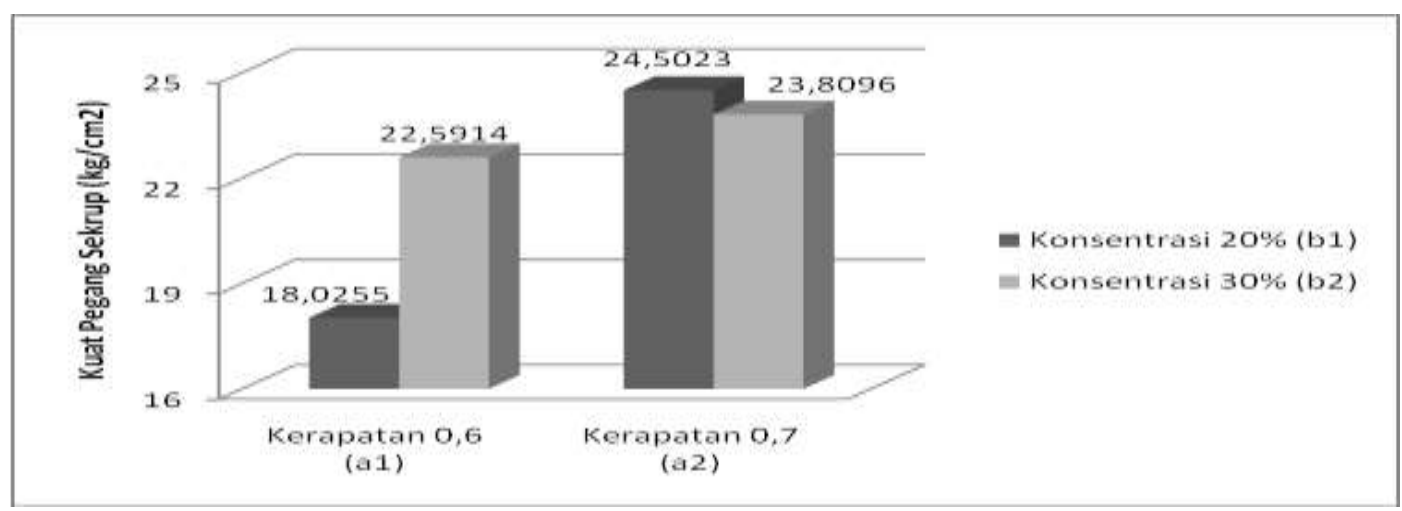

Gambar 8. Kuat pegang sekrup $\left(\mathrm{kg} / \mathrm{cm}^{2}\right)$ papan partikel dari ampas batang sagu (Metroxylon spp) dengan perekat alami asam sitrat.

Secara umum semakin meningkat kerapatan dan konsentrasi perekat semakin bertambah nilai kuat pegang sekrup, hal ini diduga dengan bertambah perekat akan terjadi ikatan yang baik antar partikel. Namun pada kerapatan 0,7 konsentrasi $30 \%$ mengalami penurunan, diduga pada konsentrasi tersebut perekat sudah tidak optimal lagi, kurang matang perekat dan papan cenderung lunak.

Semakin tinggi nilai kerapatan bertambah pula nilai kuat pegang sekrup.
Hal ini juga dinyatakan oleh Haygreen dan Bowyer (1996), bahwa kekuatan menahan sekrup terutama ditentukan oleh kerapatan papan, semakin tinggi kerapatan semakin tinggi nilai kuat pegang sekrup, hasil penelitian didukung oleh Sumardi dkk (2004), yang menyatakan bahwa semakin tinggi kerapatan maka semakin padat dan kompak pula partikel yang menyusun dari lembaran papan partikel sehingga menghasilkan kuat pegang sekrup yang lebih baik. 
JURNAL HUTAN LESTARI (2019)

Vol. 7 (1) : 166 - 177

Keawetan Papan Partikel Terhadap

Rayap Tanah

9. Mortalitas Rayap
Mortalitas rayap papan partikel ampas sagu berkisar antara 94,6 - $100 \%$. Nilai rata-rata kadar air dapat dilihat pada Gambar 9.

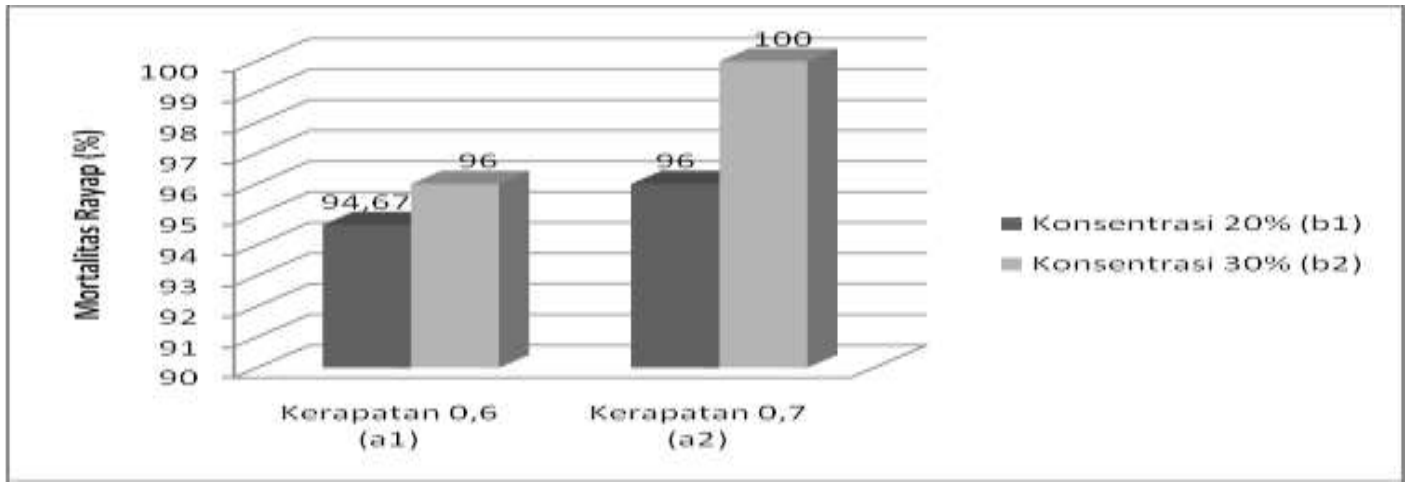

Gambar 9. Mortalitas rayap (\%) papan partikel dari ampas batang sagu (Metroxylon spp) dengan perekat alami asam sitrat.

Secara umum dilihat dari klasifikasi tingkat mortalitas semakin tinggi kerapatan dan konsentrasi maka semakin tinggi pula tingkat kematian rayap, setelah dilakukan pengujian selama 21 hari. Hal ini sejalan dengan penelitian Widyorini dkk (2015), penambahan persentase asam sitrat menyebabkan peningkatan mortalitas rayap yang tinggi. Tingginya nilai mortalitas diduga dipengaruhi juga oleh kandungan zat ekstraktif yang tinggi pada ampas sagu.

Faktor lain yang diduga berpengaruh terhadap tingginya nilai mortalitas rayap papan partikel ampas sagu adalah penguapan asam sitrat yang terkandung dalam papan partikel sehingga ada aroma khas dari papan partikel yang menyelimuti papan partikel selama proses pengujian 21 hari. Berdasarkan hal tersebut, diduga rayap mengalami dehidrasi yang kemudian menjadi faktor kematian rayap.

\section{Kehilangan Berat Papan Partikel}

Kehilangan berat papan partikel ampas sagu berkisar antara 16,9225 $36,3216 \%$. Nilai rata-rata kadar air dapat dilihat pada Gambar 10. 


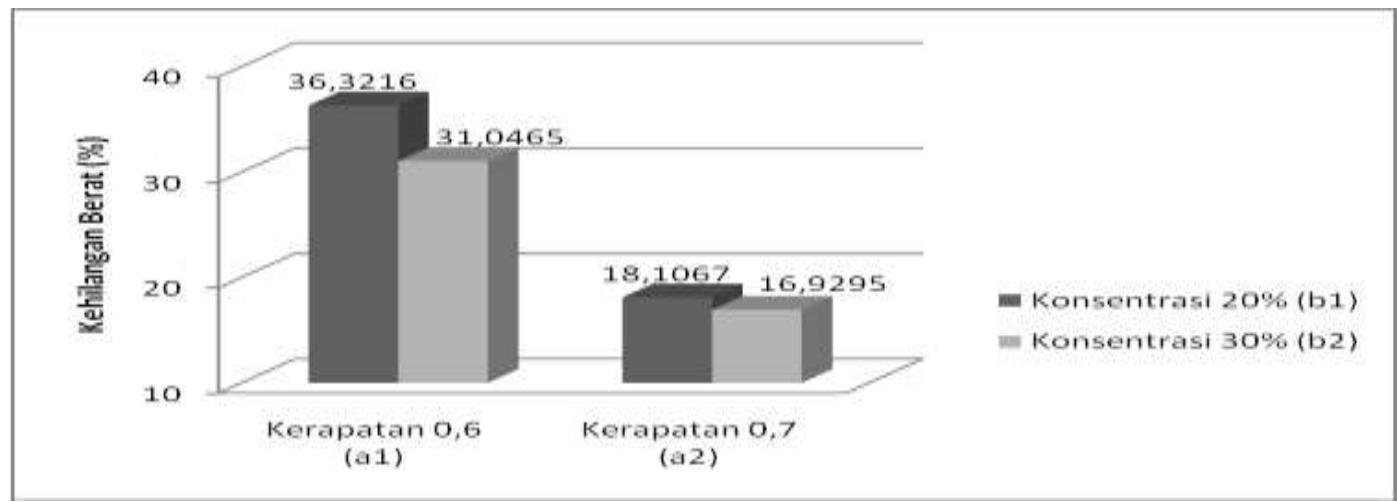

Gambar 10. Kehilangan berat (\%) papan partikel dari ampas batang sagu (Metroxylon spp) dengan perekat alami asam sitrat.

Hasil penelitian menunjukan bahwa semakin tinggi kerapatan semakin rendah kehilangan berat hal ini diduga karena, semakin tinggi kerapatan maka semakin kompak ikatan kimia papan partikel sehingga secara tidak langsung menjadi pengahambat fisik rayap sulit untuk memakan sampel uji kerapatan 0,7 dibandingkan kerapatan 0,6. Kerapatan dan kekerasan yang tinggi pada bagian luar papan diduga menjadi penghalang fisik (physical barrier) bagi rayap untuk menyerang papan (Suhasman dkk, 2010).

Papan partikel yang telah mengalami proses pengempaan pada suhu tinggi memiliki tingkat kerapatan yang berbeda ada bagian luar ke tengah. Bagian tengah memiliki kerapatan paling rendah, dibandingkan dengan bagian luar memiliki kerapatan paling tinggi.

\section{PENUTUP}

1. Papan partikel yang memenuhi standar JIS A 5908-2003 memiliki sifat fisik adalah kerapatan, kadar air, daya serap air dan sifat mekanik keteguhan rekat $(I B)$. Terdapat pada perlakuan kerapatan $0,7 \mathrm{~g} / \mathrm{cm}^{3}$ konsentrasi $20 \%$.

2. Papan partikel dengan nilai keawetan (mortalitas dan kehilangan berat) terhadap rayap tanah C. curvignathus Holmgren yang paling tinggi terdapat pada perlakuan kerapatan $0,7 \mathrm{~g} / \mathrm{cm}^{3}$ konsentrasi $30 \%$.

3. Papan partikel dengan faktor kerapatan dan konsentrasi asam sitrat yang optimal berdasarkan hasil uji sifat fisik, mekanik dan keawetan terhadap serangan rayap tanah (C. curvignathus Holmgren) adalah pada perlakuan kerapatan $0,7 \mathrm{~g} / \mathrm{cm}^{3}$ dan konsentrasi $20 \%$.

\section{DAFTAR PUSTAKA}

Badan Litbang Kehutanan. 2007. Potensi Sagu, Kendala dan Prospek Pengembanganya. Bogor. Badan Litbang Kehutanan.

Bowyer JL, Shmulky R, Haygreen JG. 2003. Forest Product and Wood Science An Introduction. Fourt Edition. Iowa State Press. 
Endriani B. 2018. Kualitas Papan Partikel dari Ampas Sagu pada Beberapa Variasi Ukuran Partikel dan Kadar Asam Sitrat. Skripsi Fakultas Kehutanan Universitas Tanjungpura.

Fauziah, Wahyuni D, Lapanporo BP. 2014. Analisis Sifat Fisik dan Mekanik Papan Partikel Berbahan Dasar Sekam Padi. Positron 4(2): 60-63

Fernando, Widyorini R, Sulistyo J, Santoso M. 2015. Pengaruh Penambahan Perekat dan Suhu Kempa Terhadap Sifat Papan Komposit dari Serat Sabut Kelapa (Cocos nucifera) dengan Asam Sitrat sebagai Perekat. Prosiding Seminar Nasiona XVIII MAPEKI 4-5 November 2015, Bandung.

Haryanto, B. P. Pangloli. 1992. Potensi dan Pemanfaatan Sagu. Penerbit Kansius, Yogyakarta, 140p.

Haygreen J.G dan J.L Boywer. 1996. Hasil Hutan dan ilmu kayu. Suatu Pengantar. Hadikusumo, SA. Penerjemah; Prawirohatmodjo S, editor. Terjemahan dari: Forest Product And Wood Science, An Introduction. Gajah Mada University Press. Yogyakarta.

Iswanto AH. 2005. Rayap Sebagai Serangga Perusak Kayu dan Metode Penanggulangannya. Jurusan Kehutanan. Fakultas Pertanian. Universitas Sumatera Utara.

JIS A 5908-2003. Palticleboard. Japanese Industrial Association. Japan.

Jumantara BA. 2011. Modifikasi Selulosa Ampas Sagu dengan Polimerisasi Pencangkokan dan
Penautan-Silangan.Skripsi

Fakultas Matematika dan Ilmu Pengetahuan Alam Institut Pertanian Bogor.

Kusuma ES. 2012. Pengujian Panel Akustik Papan Partikel Kayu Sengon (Paraserianthes falcatarian). Skripsi Fakultas Kehutanan Institut Pertanian Bogor.

Lestari M, Setyawati D, Nurhaida. 2018. Karakteristik Papan Partikel dari Ampas Sagu dan Perekat Asam Sitrat Berdasarkan Kerapatan Papan. Jurnal Hutan Lestari. Fakultas Kehutanan Universitas Tanjungpura. Vol. 6, No 2.

Maulana D, Dirhamsyah, Setyawati D. 2015. Karakteristik Papan Partikel dari Batang Pandan Mengkuang (Pandanus atrocarpus Griff ) Berdasarkan Ukuran dan Konsentrasi Ureaformaldehida. Jurnal Hutan Lestari. Vol 3, No. 2.

McSweeny JD, Rowell RM, Min S. 2006. Effect of Citric Acid Modification of Aspen Wood on Sorption of Copper Ion. Jurnal of Natural Fibers 3(1), 43-58.

Nandika D, Rismayadi Y, Diba F. 2003. Rayap biologi dan Pengendaliannya. Surakarta: Muhammadiyah University Press.

Nurhaida dan Setyawati D. 2017. Laporan hasil Penelitian. Universitas Tanjungpura, Fakultas Kehutanan.

SNI 01-7207-2006. Uji Ketahanan Kayu dan Produk Kayu Terhadap Organisme Perusak Kayu. Standar Nasiona Indonesia. Indonesia. 
Sumardi I, Darwis A, dan Hadian H. 2004. Pengaruh Kerapatan dan Ukuran Partikel Terhadap Sifat Fisis dan Mekanis Papan Partikel Kayu Suren (Toona Sureni Merr). Prosiding Nasional Masyarakat Penelliti Kayu Indonesia ( MAPEKI) VII. Makasar.

Suhasman, Massijaya Y, Hadi YS, Santoso A. 2010.Karakteristik Papan Partikel Dari Bambu Tanpa Menggunakan Perekat.Jurnal Ilmu dan Teknologi Hasil Hutan. Vol. 3, No. 1.

Widyorini R, Prayitno TA, Yudha AP, Setiawan BA, dan Wicaksono BH. 2012. Pengaruh Konsentrasi Asam Sitrat dan Suhu Pengempaan Terhadap Kualitas Papan Partikel DariPelepah
Nipah. Jurnal Ilmu Kehutanan. Vol. VI, No.1.

Widyorini R, Nugraha AP. 2015. Sifat Fisik Dan Mekanik Papan Partikel Sengon Dengan Perekat SitratSukrosa. J.Ilmu Teknologi Kayu Tropis Vol.13, No.2.

Widyorini R, Yudha AP, Lukamandaru G, Prayitno TA. 2015. Sifat Fisika Mekanika dan Ketahanan Papan Partikel Bambu dengan Perekat Asam Sitrat Terhadap Serangan Rayap Kayu Kering. Jurnal Ilmu Kehutanan. Vol 9. No. 1.

Wulandari. 2012. Deskripsi Sifat Fisika dan Mekanika Papan Partikel Tangkai Daun Nipah (Nypa fruticans. Wurmb) Dan Papan Partikel Batang Bengle (Zingiber cassumunar. Roxb) Jurnal Media Bina Ilmiah (6:6) (7-11) 